\title{
Trade, productivity and profitability: On profit levels and profit margins
}

\author{
Marcel van den Berg ${ }^{1}$ (D) | Charles van Marrewijk ${ }^{2}$ | Saara Tamminen ${ }^{3}$ \\ ${ }^{1}$ Centraal Bureau voor de Statistiek, Heerlen, The Netherlands \\ ${ }^{2}$ Utrecht School of Economics, Utrecht University, Utrecht, The Netherlands \\ ${ }^{3}$ VATT Institute for Economic Research, Helsinki, Finland \\ Funding information \\ Ministry of Economic Affairs and the Ministry of Foreign Affairs of the Netherlands
}

\section{1 | INTRODUCTION}

Are firms engaging in international trade more profitable than domestic firms? The assumption of profit maximisation lies at the heart of economic theory regarding firm behaviour. Although recent surveys (Melitz \& Redding, 2014; Wagner, 2012b) list many studies providing empirical evidence that internationally competing firms are on average more productive than domestically competing firms, the number of studies on the differences in profitability is much smaller and covers only a few European countries. As we discuss below, the fact that these studies do not lead to clear conclusions regarding the relationship between internationalisation and profitability, in contrast to the positive connection with productivity, seems puzzling to researchers in search for a positive link between these two forces. This paper seeks to partially clarify this puzzle.

The relatively small number of empirical studies on the link between profitability and internationalisation compared to the large number of studies on the link between productivity and internationalisation is mainly caused by the additional informational requirements needed to adequately calculate profitability. The link between internationalisation and profitability is, however, important from an empirical and practical point of view. Financial analysts generally evaluate firm performance based on information provided in financial statements in which profitability indicators play an important role (Robinson, van Greuning, Henry, \& Broihahn, 2012). Profitability information is thus crucial in the decision-making process of investors, thereby affecting the availability of funds for the firm. Consequently, various studies ${ }^{1}$ have found that firms with low profitability, as measured by the return on assets (ROA) or net profit margins, are most likely to exit the market. Low profit margins can also lead to mass layoffs of employees and downsizing (Marques, Conzález, \& Cruz, 2011; McKinley, Zhao, \& Rust, 2000). An empirical study on the relations between internationalisation and profitability is therefore welcome from a practical point of view.

We contribute to the analysis on the links between trade, productivity and profitability in three ways.

\footnotetext{
${ }^{1}$ For example, Bottazzi, Grazzi, Secchi, and Tamagni (2011), Bridges and Guariglia (2008), Ilmakunnas and Topi (1999), Iwasaki (2014) and Tamminen (2016).
} 
- First, we argue in the remainder of this introduction that part of the confusion on the links between trade, productivity and profitability arises from not clearly distinguishing between profit levels and profit margins, as well as not clearly identifying the impact of productivity.

- Second, we use two theoretical models, namely the Melitz (2003) model and the Egger and Kreickemeier (2012) model, to clarify the relationship between productivity, trade activity and profit margins and derive three hypotheses: (I) profit margins rise as productivity rises for domestic firms; (II) profit margins rise as productivity rises for trading firms; and (III) profit margins are not higher for trading firms than for domestic firms.

- Third, we test these hypotheses empirically using two detailed, firm-level data sets for two European countries: Finland and The Netherlands. We believe, as Hamermesh (2000, p. 376), puts it, that "the credibility of a new finding that is based on carefully analysing two data sets is far more than twice that of a result based only on one." In addition, Wagner (2011, p. 406) recommends never to consider "results based on one sample of firms from one country and from one period of time as a stylised fact."

To clarify our points, we use the following terminology throughout the paper:

- The term profit level refers to total firms profits in a certain period.

- The term profit margin refers to relative profits, that is the profit level in some period relative to some other economic variable, like firm revenue or firm employment.

- The term profitability is used in a vague way and can refer to either the profit level or the profit margin, as is customary in much of the literature.

Naturally, one expects, other things equal, that more productive firms are also more profitable. The point is, of course, that other things are not equal. More productive firms tend to self-select into internationalisation activities (exports, imports and two-way trade). Associated with these activities are additional costs and investments related to selling and buying on international markets, such as market research, locating foreign trade partners or modifying products to comply with local regulations and preferences. In addition, more productive firms generally have a higher skilled and more productive workforce, which requires paying higher wages and thus leads to higher costs (Egger \& Kreickemeier, 2012).

Theoretical models regarding the behaviour of individual firms on international markets are based on the notion that a firm engages in internationalisation if the expected profit level from doing so is positive, leading to self-selection of more productive firms (able to pay for the additional costs) into internationalisation activities (Clerides, Lach, \& Tybout, 1998; Egger \& Kreickemeier, 2012; Melitz, 2003). The marginal trading firm and the firms with a productivity level slightly above it thus engage in trade activities. This leads to a (slightly) higher profit level and increase in the scale of production, but also to a decline in profit margins as the margin on the trading activities is close to zero, in contrast to the profit margin on domestic sales.

In the empirical sections, we analyse four different main sectors, namely manufacturing sectors in both countries, service sectors in Finland and wholesale \& retail trade in the Netherlands. We also identify three types of trading firms (namely, exporting firms, importing firms and two-way traders) for all main sectors, except for the service sector in Finland (where we identify only two types of trading firms, namely importers and services exporters). In total, this thus gives us 11 different tests $(3 \times 3+2)$ of our three hypotheses. We find strong support for Hypothesis I for all tests (in favour of the Melitz model), strong support for Hypothesis II for all tests (in favour of 
both models) and pretty strong support for Hypothesis III (namely 10 of 11 tests; which is in favour of the Egger-Kreickemeier model).

The paper is organised as follows. Section 2 briefly discusses the existing empirical literature on the relationship between internationalisation and profitability. Section 3 reviews the theoretical framework for this relationship and derives simple testable hypotheses. Section 4 introduces the Finnish and Dutch data sets used in the analysis. Section 5 discusses the measurement of profitability and the methodology adopted in the empirical analysis. Section 6 presents our empirical findings, and Section 7 discusses the theoretical implications of our empirical findings. Section 8 concludes.

\section{2 | FIRM HETEROGENEITY, PRODUCTIVITY AND PROFITABILITY}

We briefly review the empirical studies on the link between internationalisation and profitability, both from an international economics point of view (where there are relatively few studies in the firm heterogeneity literature) and an international business point of view (where there are many, mainly survey-based and small sample studies). We start with exporting firms and then briefly discuss trade premia for importing firms and two-way traders at the end of this section.

Various theoretical and empirical studies implicitly or explicitly expect that the productivity premium for exporters translates into a profitability premium as well; see Wagner (2012b, p. 253) for a survey. ${ }^{2}$ On the link between profitability and internationalisation, he notes, however, that: "As of today, a big picture has not emerged". Girma, Görg, and Strobl (2004), employing a series of Kolmogorov-Smirnov tests, find no significant difference between domestic non-exporters and domestic exporters for the profits per employee. Grazzi (2012) finds no significant relationship between exporting and profit margins in Italy, which is similar to the findings of Temouri, Vogel, and Wagner (2013) for British service exporters and Wagner (2012a) for Germany. Temouri et al. (2013) find a positive relationship between service exporting and profit margins in France and a negative relationship in Germany. In addition, Fryges and Wagner (2010) document a small exporter premium on profit margins for German manufacturing firms, but a small negative premium if the share of exports in total sales is small. Kox and Rojas-Romagosa (2010) present evidence for the Netherlands that profits per employee in exporting firms are higher and that more profitable firms seem to self-select into exporting activities. ${ }^{3}$

In the field of international business, the relationship between internationalisation and firm performance has been heavily debated over the past decades. In their meta-analysis, Bausch and Krist (2007, p 320) summarise the current state of affairs in a series of citations as: "inconsistent," "mixed," "decidedly mixed," "contradictory," "inconsistent and contradictory," "inconclusive and contradictory" and "conflicting." "Similarly, Sousa (2004) reviews 43 empirical papers published between 1998 and 2004 and argues that little consensus has been reached in the field, which has produced contradictory and fragmented findings thus far. An important drawback of this type of

\footnotetext{
${ }^{2}$ Our discussion in this section is based on this survey; see in particular table 5 of Wagner (2012b).

${ }^{3}$ Differences between our findings and those of Kox and Rojas-Romagosa (2010) should be interpreted with caution because the underlying data cover different time periods and are derived from different source data.

${ }^{4}$ Based on 36 studies from 25 years of research (41 samples, $N=7,792$ ), they nonetheless suggest that internationalisation fosters firm performance, although the link is heavily affected by other characteristics, such as the size and age of the firm.
} 
research in international business management is the fact that the performance of, for example, exporters is not related to that of importers, two-way traders or domestic firms. This makes it difficult to claim that exporting in itself does or does not foster firm performance, since a benchmark against which the performance of exporters is evaluated is lacking. Moreover, since many studies are survey based, contain relatively small samples, use different methodologies and rely on various measures of internationalisation and profitability, generalisation of the findings is a delicate endeavour.

The main conclusion we draw from the discussion above is that no consensus has been reached thus far regarding the link between exporting and profitability, neither in the field of international economics nor in international business management.

The link between profitability and importing firms or two-way traders is hardly analysed, with Wagner (2012a) as a prominent exception. Using robust estimation methods, he finds no significant effects on trade status for East Germany and a negative (rather than positive) effect for importers and two-way traders for West Germany; see Wagner (2012a, table 5). ${ }^{5}$ Although initially under-analysed, there are now a number of studies linking importing and two-way trading firms with productivity measures, which usually find that these firms are indeed more productive than firms that source inputs solely domestically. Vogel and Wagner (2010) employ a panel data set of German manufacturing firms and argue that more productive firms self-select into importing. These findings are largely congruent with related studies by Andersson, Löö, and Johansson (2008), Eriksson, Smeets, and Warzynski (2009), Kasahara and Lapham (2008) and Muûls and Pisu (2009). Evidence supporting the learning-by-importing hypothesis is presented by Lööf and Andersson (2010) and Hagemejer and Kolasa (2011). van den Berg and van Marrewijk (2017) argue that geography (what country is imported from) and factor intensity (what type of good is imported) also play a role to determine firm productivity.

In their contribution on the importance of "global firms" that can affect market outcomes relative to smaller monopolistic firms that cannot, Bernard, Jensen, Redding, and Schott (2017) also summarise the empirical information on the trade premia relative to domestic firms for three different groups of firms, namely exporters, importers and, exporters and importers for the USA; see Figure 1. All premia control for sector fixed effects and employment size (except, of course, employment itself, which only has sector fixed effects). All premia are highly significant. The trade premia for importers are higher than for exporters (except for total factor productivity and wages), while the trade premia for exporters and importers are higher than for importers (except for total factor productivity, which is the same). In any case, we can conclude that firms engaging in trade activities have significantly higher employment, shipments, value added per worker, total factor productivity, capital per worker and skills per worker and they also pay higher wages than domestic firms. See also Figure 4 below for the productivity distribution of Dutch firms.

\section{3 | THEORETICAL FRAMEWORK}

To link the empirical distribution to some basic theoretical frameworks, we briefly analyse profit margins for domestic and exporting firms in the Melitz model and the Egger-Kreickemeier model. We discuss importing firms and two-way traders at the end of this section.

\footnotetext{
${ }^{5}$ These effects disappear for the firm fixed effects estimates.
} 
(a)
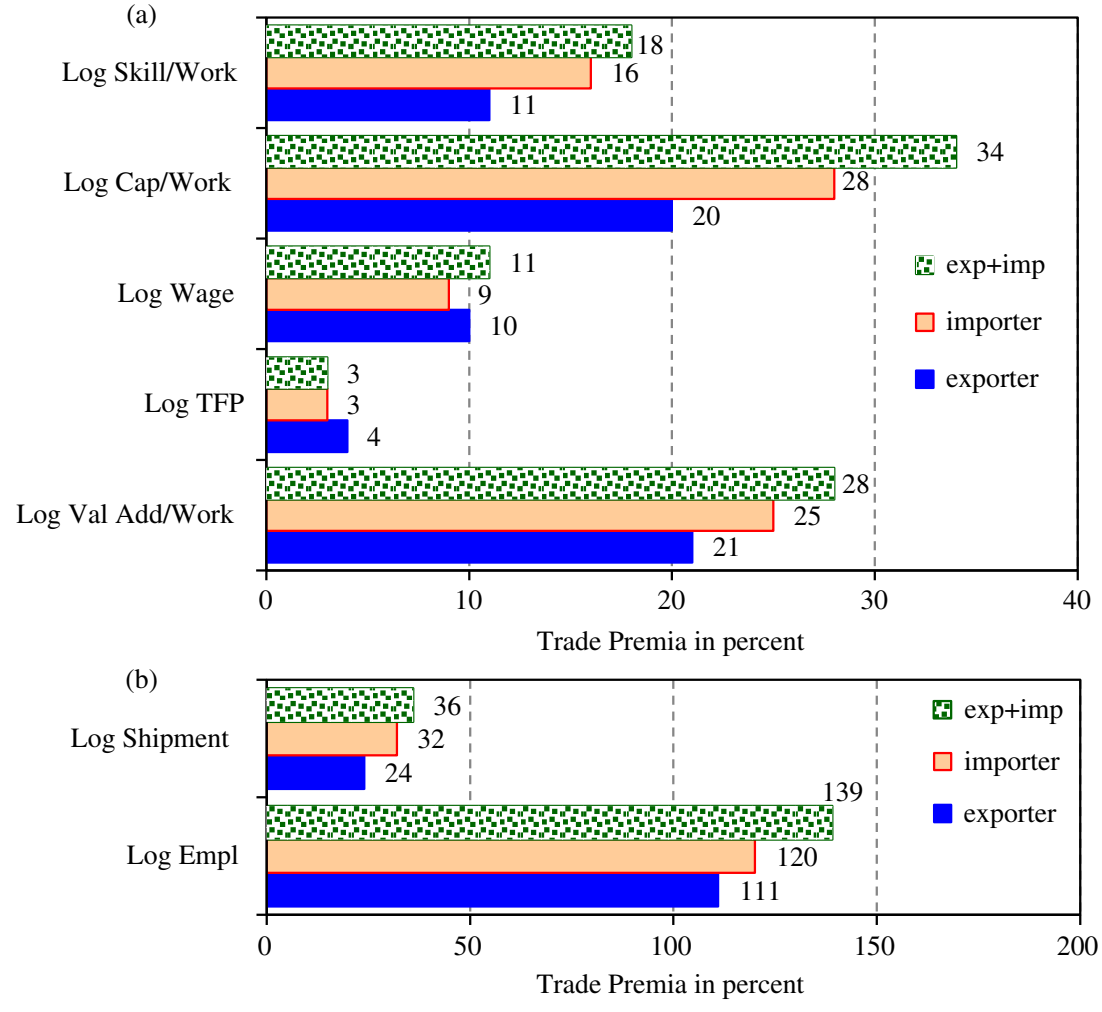

FIGURE 1 Trade premia in per cent; USA, 2007

Source: van Marrewijk (2017), based on data in Bernard et al. (2017); exp + imp = exporter \& importer; all bivariate OLS regressions with industry fixed effects \& log employment (except log employment itself); skill/work $=$ skill per worker; cap/work $=$ capital per worker; TFP $=$ total factor productivity; Val add/work = value added per worker; Empl = employment. [Colour figure can be viewed at wileyonlinelibrary.com]

As noted above, the decision to produce at all and the decision to engage in export activity are based on the profit level associated with these activities. ${ }^{6}$ Let $\varphi$ denote the firm's productivity level, $r_{d}(\varphi)$ the domestic revenue generated by a firm with this productivity level, $\pi_{d}(\varphi)$ its domestic profit level, $r_{x}(\varphi)$ the export revenue, and $\pi_{x}(\varphi)$ its export profit level. Obviously, both domestic and foreign revenue and both domestic and foreign profits are rising functions of productivity. In both settings below, there are threshold productivity levels $\varphi_{d}^{*}$ and $\varphi_{x}^{*}$ for viability and exporting, respectively, such that firms engage in domestic production if $\varphi \geq \varphi_{d}^{*}$ and in export activity if $\varphi \geq \varphi_{x}^{*}$. In both settings, the exporting threshold is higher than the viability threshold: $\varphi_{x}^{*} \geq \varphi_{d}^{*}$. We therefore first have a range of productivity levels in which the firm is not viable, followed by a range of productivity levels in which the firm only produces for the domestic market, and concluded by a range of productivity levels in which the firm sells both domestically and on the export market. In the analysis below, we focus on the profit margin and not the profit level, as this is the focus of financial analysts (see Section 1). We measure the profit margin by dividing the profit level by the firm's total revenue and label it $\tilde{\pi}$.

\footnotetext{
${ }^{6}$ To streamline the analysis, we investigate only a 2-country model, but the symmetric multicountry analysis is straightforward.
} 


\section{1 | Profit margins in the Melitz model}

In the Melitz model, operating profits are a fraction $1 / \sigma$ of the firm's revenue in the respective market, where $\sigma>1$ is the price elasticity of demand. Before the firm can engage in production, it has to overcome a fixed cost equal to $f_{d}$ in the domestic market and equal to $f_{x}$ in the foreign market. Firms engaged in exports incur higher marginal costs at the rate $\tau>1$ (per unit iceberg costs). To ensure that the above-discussed partitioning of firms by export status holds (which is widely observed empirically), Melitz assumes (as do we) that $f_{x}>\tau^{1-\sigma} f_{d}$. In the geographical economics literature, the parameter combination $\tau^{1-\sigma}$ is generally referred to as the "freeness of trade"; see Brakman, Garretsen, and van Marrewijk (2009). ${ }^{7}$ We use $\alpha \equiv \tau^{1-\sigma}$ for this freeness of trade, which will be useful also in this setting. ${ }^{8}$ Note that the freeness of trade ranges from zero (when $\tau$ is arbitrarily large for any given $\sigma$ ) to one (when $\tau=1$ ). The partitioning condition above can then be written as $f_{x}>\alpha f_{d}$ :

$$
\tilde{\pi}_{j}(\varphi) \equiv \frac{\pi_{j}(\varphi)}{r_{j}(\varphi)}=\frac{\left[\frac{r_{j}(\varphi)}{\sigma}\right]-f_{j}}{r_{j}(\varphi)}=\frac{1}{\sigma}-\frac{f_{j}}{r_{j}(\varphi)} ; \quad j=d, x ; \quad \varphi_{j}^{*} \leqslant \varphi .
$$

The main characteristics for profit margins in the domestic and foreign markets are simple to derive; see Equation (1). Since the profit level is zero at the threshold productivity level, so is the profit margin at this point: $\tilde{\pi}_{d}\left(\varphi_{d}^{*}\right)=0=\tilde{\pi}_{x}\left(\varphi_{x}^{*}\right)$. Since revenue rises with productivity, so does the profit margin: $\tilde{\pi}_{d}^{\prime}(\varphi)>0$ and $\tilde{\pi}_{x}^{\prime}(\varphi)>0$, with an upper bound of $1 / \sigma$ in both cases: $\lim _{\varphi \rightarrow \infty} \tilde{\pi}_{d}(\varphi)=\lim _{\varphi \rightarrow \infty} \tilde{\pi}_{d}(\varphi)=1 / \sigma$.

It is also straightforward to rank the profit margin in the domestic market relative to the profit margin in the foreign market. More precisely, using the fact that the revenue in the foreign market is a fraction $\alpha$ (indeed, the freeness of trade) of the revenue in the domestic market $\left(r_{x}(\varphi)=\alpha r_{d}(\varphi)\right)$, it follows that the profit margin in the foreign market is lower than in the domestic market if, and only if, $f_{x}>\alpha f_{d}$ since:

$$
\begin{gathered}
\tilde{\pi}_{x}(\varphi)=\frac{1}{\sigma}-\frac{f_{x}}{r_{x}(\varphi)}<\frac{1}{\sigma}-\frac{f_{d}}{r_{d}(\varphi)}=\tilde{\pi}_{d}(\varphi) \Longleftrightarrow \frac{f_{x}}{r_{x}(\varphi)}>\frac{f_{d}}{r_{d}(\varphi)} \Longleftrightarrow \\
\frac{f_{x}}{r_{x}(\varphi)}=\frac{f_{x}}{\alpha r_{d}(\varphi)}>\frac{f_{d}}{r_{d}(\varphi)} \Longleftrightarrow f_{x}>\alpha f_{d} .
\end{gathered}
$$

This is the same condition as the condition for the partitioning of firms by export status already discussed above (and assumed to hold). The profit margin in the export market is thus lower than the profit margin in the domestic market for any arbitrary level of productivity.

Now that we have discussed profit margins in the two separate markets, we are also able to determine the (overall) profit margin that we should observe for firms producing only for the domestic market (with productivity between the domestic threshold and the exporting threshold) and for firms also engaged in exporting (with productivity above the exporting threshold). For firms producing only for the domestic market, this profit margin is simply equal to domestic profit margin. If we recall that $r_{x}(\varphi)=\alpha r_{d}(\varphi)$, it is clear that for firms that also export, the overall profit margin is equal to a weighted average of the domestic profit margin and the export profit margin.

\footnotetext{
${ }^{7}$ Also referred to as the new economic geography literature.

${ }^{8}$ The literature mostly uses $\phi$ for the freeness of trade, but we want to avoid confusion between $\phi$ and $\varphi$.
} 


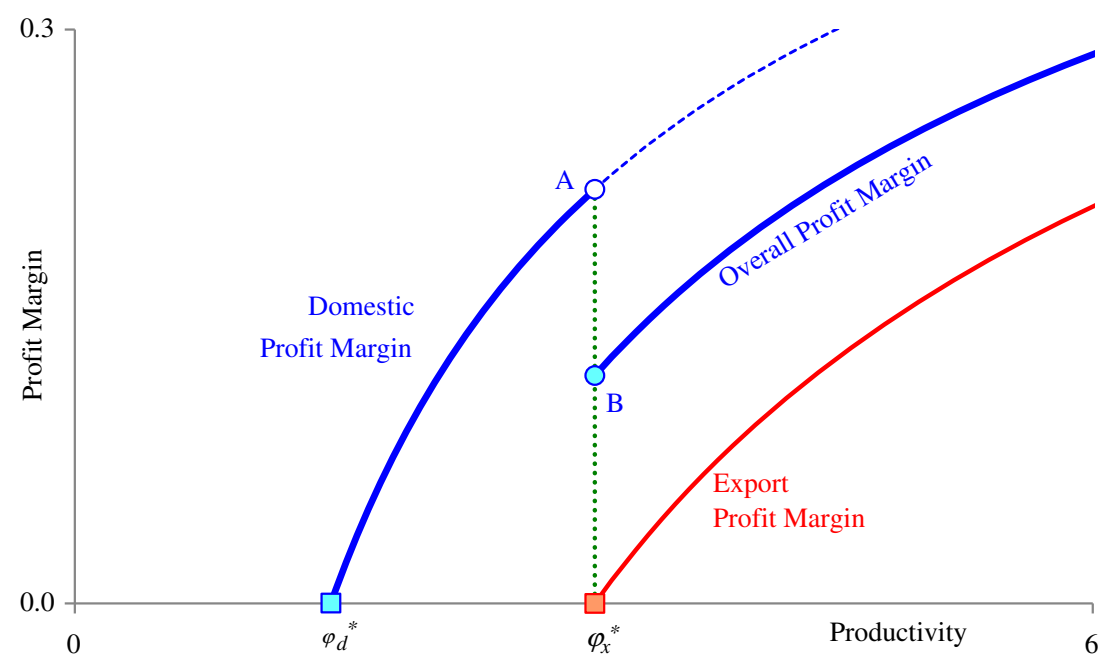

FIGURE 2 Profit margins in the Melitz model [Colour figure can be viewed at wileyonlinelibrary.com]

$$
\tilde{\pi}(\varphi)= \begin{cases}\frac{\pi_{d}(\varphi)}{r_{d}(\varphi)}=\tilde{\pi}_{d}(\varphi) ; & \text { for } \varphi_{d}^{*} \leqslant \varphi<\varphi_{x}^{*} \\ \frac{\pi_{d}(\varphi)+\pi_{x}(\varphi)}{r_{d}(\varphi)+r_{x}(\varphi)}=\frac{1}{1+\alpha} \tilde{\pi}_{d}(\varphi)+\frac{\alpha}{1+\alpha} \tilde{\pi}_{x}(\varphi) ; & \text { for } \varphi_{x}^{*} \leqslant \varphi\end{cases}
$$

Figure 2 summarises our findings. We do not observe any firms below the domestic threshold $\varphi_{d}^{*}$. Firms producing only for the domestic market start with a profit margin of zero at the domestic threshold, which rises to a maximum denoted by point $\mathrm{A}$ in Figure 2 for firms approaching the export threshold $\varphi_{x}^{*}$. The marginal exporting firm at the export threshold $\varphi_{x}^{*}$ is confronted with a fall in its profit margin (but not in profit level) at point B in Figure 2 because its overall profit margin is a weighted average of the profit margins in the two markets and the profit margin in the domestic market is always higher than in the export market for any given productivity level. As productivity rises without bound, the overall profit margin of the firms engaged in exporting will always be higher than that of even the most productive domestic firm as both the domestic profit margin and the export profit margin approach the same upper bound $1 / \sigma$ (which must therefore also hold for its weighted average), which is higher than the productivity at point A. Whether such firms exist is an empirical matter also discussed below.

\section{2 | Profit margins in the Egger and Kreickemeier model}

The Egger-Kreickemeier model incorporates similar firm heterogeneity features as the Melitz model. First, there is a viability threshold, such that the least productive firms do not produce. Second, there is a higher exporting threshold, such that only the most productive firms export and we have a partitioning of firms by export status. Third, there are higher marginal costs associated with exporting (iceberg costs $\tau$ ) as well as fixed costs $f_{x}$. Fourth, there are (productivity) gains from trade.

There are, however, also several distinguishing features of the Egger-Kreickemeier model. Production in firms requires two types of labour: one manager and a range of workers. The ability of the manager determines productivity and the number of workers to hire. The labour market is based on a variant of the fair-wage effort mechanism developed by Akerlof and Yellen (1990). In bargaining with the firm, the workers take into consideration: (i) a reference wage (which depends 
on unemployment and the average wage paid elsewhere); and (ii) the firm's performance (based on operating profits). As a consequence, more productive firms pay higher wages, as is observed empirically. In addition, because of the discontinuity associated with operating profits once productivity reaches the export threshold, exporting firms pay an extra wage premium, as is also observed empirically.

For simplicity, we use the same notation for profit margins, the profit level and revenue as in the Melitz model. Note, however, that the underlying functions are of course different. The discontinuity mentioned above results in a slight complication. Since exporting firms pay strictly higher wages than firms only producing for the domestic market for the same productivity level, the associated functions differ as well. We denote this by an extra sub-index $x$, that is $r_{d}(\varphi)$ denotes revenue in the domestic market for firms only producing in the domestic market and $r_{d x}(\varphi)$ denotes revenue in the domestic market for firms that also export, and so on. ${ }^{9}$

The Egger-Kreickemeier model is quite ingenious in the way it determines the viability and exporting thresholds. Economic agents can decide to become either a manager, a production worker or a local expert for exporting firms. The agents can be ranked according to their management abilities (which determines firm productivity). An agent becomes a manager if the profit level she can reach is at least equal to the reference wage mentioned above. This determines the viability threshold $\varphi_{d}^{*}$, with only the most able managers becoming entrepreneurs. To engage in export activity, the firm needs to hire a local expert in the destination market. She will have to be paid the reference wage in order to get involved, which determines the fixed cost for exporting $f_{x}$ and the export threshold $\varphi_{x}^{*}$. Note that the fact that the fixed costs for exporting are endogenously determined has no material consequences for the rest of our discussion.

As in the Melitz model, operating profits are a fraction $1 / \sigma$ of the firm's revenue. Since an economic agent becomes a manager if the profit level exceeds the reference wage and does not incur any fixed costs, the profit margin is equal to $1 / \sigma$ for these firms. For the firms engaging in export activity, the export revenue is a fraction $\alpha$ of its domestic revenue (as in the Melitz model). Since the exporting activity does incur fixed costs to pay the local expert, the profit level is thus: $\frac{(1+\alpha) r_{d x}(\varphi)}{\sigma}-f_{x}$. This implies that the profit margin for exporting firms is lower than for domestic firms:

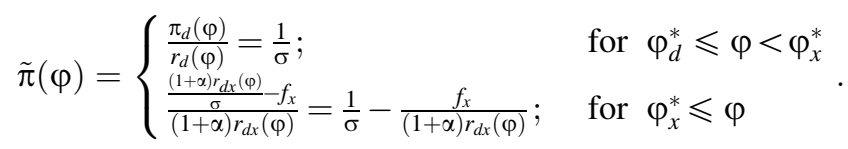

Figure 3 illustrates our findings for profit margins in the Egger-Kreickemeier model. The number of firms is determined by equality of the (endogenous) reference wage with the profit level of the marginal firm, which determines the viability threshold $\varphi_{d}^{*}$. Wages rise as the profit level rises, but the markup does not change. For domestic firms, this implies that the profit margin is constant throughout its range. Firms start to export once the combined profit level from exporting and the domestic sales exceed that of supplying only the domestic market. ${ }^{10}$ Since these firms incur a fixed cost to engage in exporting activity, the profit margin drops discontinuously from $\mathrm{A}$ to $\mathrm{B}$ at the export threshold $\varphi_{x}^{*}$. The profit margin returns back to $1 / \sigma$ from below as productivity increases.

\footnotetext{
${ }^{9}$ Because of the higher wage rate paid by exporters: $r_{d}(\varphi)>r_{d x}(\varphi)$, but remember that the firms are partitioned by productivity in equilibrium such that there is no overlap.

${ }^{10}$ Since exporting firms pay a strictly higher wage, the marginal exporting firms have lower profits on the domestic market, which must be compensated by positive profits on the export market.
} 


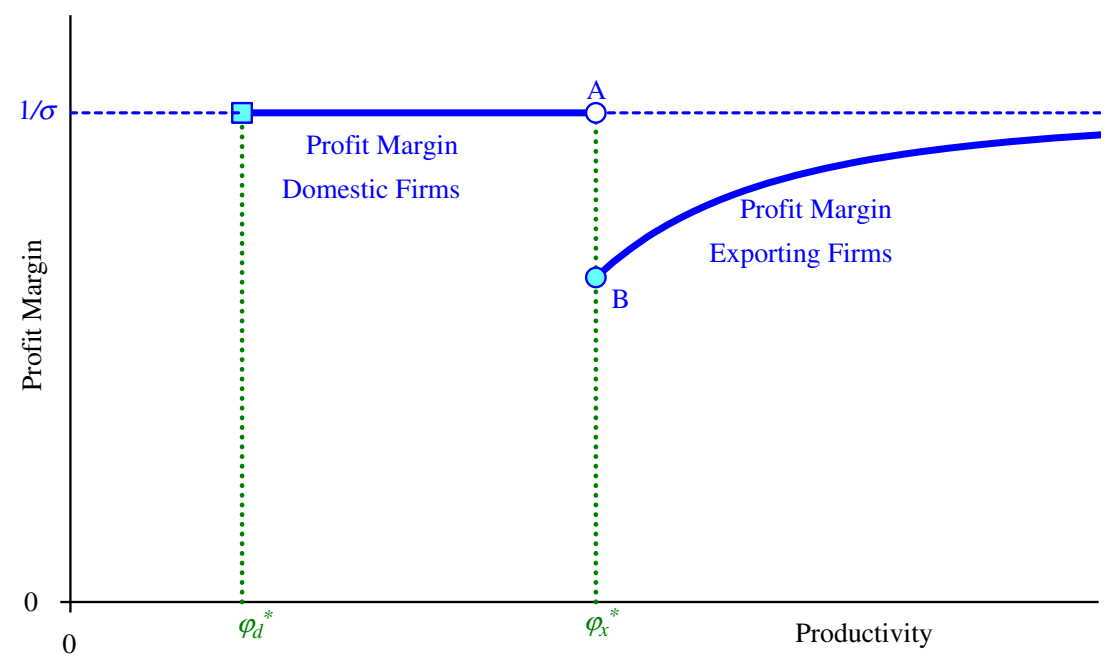

FIGURE 3 Profit margins in the Egger-Kreickemeier model [Colour figure can be viewed at wileyonlinelibrary.com]

\section{3 | Empirical implications}

Before we review the empirical implications of Sections 3.1 and 3.2, we briefly discuss a similar type of setting for other types of trading firms. For importing firms, the analysis is quite similar. More productive firms can charge lower prices and thus have higher revenues. If there is an advantage to importing goods or components from abroad in addition to a fixed cost involved to start importing, this is only possible for sufficiently productive firms. The remaining implications for the profit margins in the two different settings are then the same. For two-way traders, a similar argument holds, taking into consideration that these firms have to overcome two types of fixed costs, on the import side as well as on the export side. Again, only the most productive firms can become two-way traders and the implications for their profit margins is similar as above in the two different settings.

What are the testable empirical implications from the above discussion regarding the link between trade and profit margins? We summarise these in the following hypotheses.

Hypothesis I: Profit margins rise as productivity rises for domestic firms.

Hypothesis II: Profit margins rise as productivity rises for trading firms.

Hypothesis III: Profit margins are at least as high for domestic firms as for trading firms.

Hypothesis I on rising profit margins as productivity increases for domestic firms only holds for the Melitz model and not for the Egger-Kreickemeier model (where the profit margin is constant). This thus provides a clear distinction between the two models.

Hypothesis II holds for both models: profit margins rise as productivity increases for exporting firms, see Figures 2 and 3. Empirical support for this hypothesis is thus required for both models, but does not allow us to distinguish between the two models.

Hypothesis III only holds for the Egger-Kreickemeier model, where exporting firms have lower profit margins. We cannot draw the same conclusion for the Melitz model, where anything goes in this respect as exporting firms can have both lower and higher profit margins than domestic firms. 


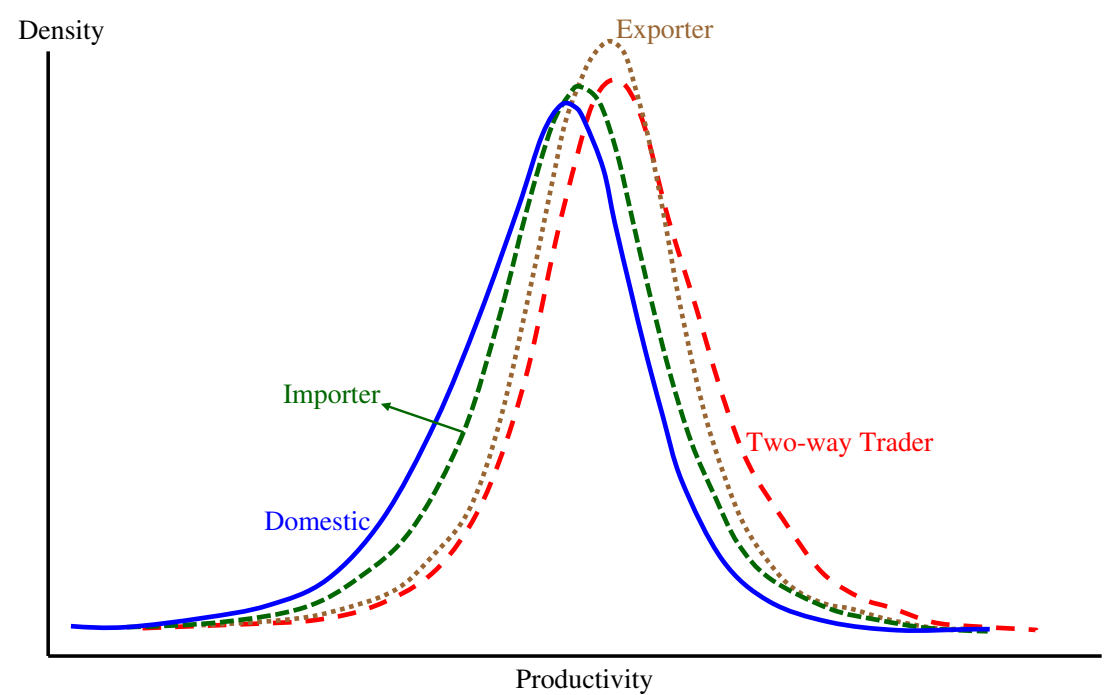

FIGURE 4 Productivity distribution for different types of Dutch manufacturing firms

Source: Authors' calculations based on firm-level data 2002-10; horizontal axis represents firm-level log labour productivity; vertical axis represents kernel density at that particular productivity level. [Colour figure can be viewed at wileyonlinelibrary.com]

Although the Melitz model is thus not falsifiable regarding the profit margin ranking of domestic relative to exporting firms (Hypothesis III), it does show that we should not be surprised if exporting firms have lower profit margins. We can go one step further if we look at the empirical distribution of productivity for domestic firms relative to different types of trading firms. This is shown for Dutch manufacturing firms in Figure 4 to illustrate two points. First, there is a certain ranking in trade type (as has been found many times before); in this case (from low to high): domestic firmsimporters-exporters-two-way traders. ${ }^{11}$ Second, there is considerable overlap in productivity for the different firm types, suggesting that most of the mass of trading firms is close to the threshold. ${ }^{12}$ Combining this information with the theoretical implications of the Melitz model illustrated in Figure 2 suggests that empirically many trading firms will be in the range where profit margins are lower than for many domestic firms. This strengthens the suggestion that we should not be surprised to find profit margins to be higher for domestic firms, even in the Melitz model.

\section{4 | DATA}

For the empirical analysis, we employ firm-level micro-data from Finland and the Netherlands. In order to gain an understanding of the consistency and robustness of our findings, we run the analysis separately for both countries. The main aim of the data preparation process is to maximise the comparability of the Finnish and the Dutch data, particularly regarding the profit margins employed. ${ }^{13}$

\footnotetext{
${ }^{11}$ A similar ranking holds for manufacturing firms in Finland and wholesale \& retail trade firms in the Netherlands. For services firms in Finland, the ranking is the same, but without the two-way trader group.

${ }^{12}$ See Chang and van Marrewijk (2013) for Latin America and Melitz and Redding (2014) for a review.

${ }^{13}$ As usual when using large micro-data sets, the source of the data are statistical agencies and confidentiality precludes these data from being publicly available. Researchers who wish to replicate the results can contact the relevant statistical agencies with a research request subject to a confidentiality agreement, which may require a fee for the agency to provide the information in usable format within a remote access environment.
} 


\section{1 | Finland}

For the Finnish analysis, we use data from the Finnish tax authorities which includes information on corporate tax declarations and income tax declarations of entrepreneurs. ${ }^{14}$ The database covers essentially all Finnish firms operating in all sectors. This study analyses Finnish data from 2005 until 2010. The tax database includes detailed financial accounts and balance sheet information for each firm and each year. The data are transformed to constant 2005 prices. Firms are classified into four size categories according to the official EU-classification. ${ }^{15}$ Microsized firms are included in the analysis, except for firms with less than 4 employees. ${ }^{16}$ In addition to the main tax database, value added tax (VAT) records are used for the identification of goods and services exporters and firms importing goods from the EU. Exporters' identification is only possible in selected service sectors due to data limitations. ${ }^{17}$ Firms belonging to other service sectors are not included in the analysis. The database also allows the identification of multinational firms, which are identified from the legal form of the firm and from the information on foreign subsidiaries. The firms are grouped into 70 sectors, which correspond roughly to a combination of NACE 2 and 3-digit classifications. Since services and manufacturing exporters have typically different types of production processes, manufacturing sectors and service sectors are considered separately. ${ }^{18}$ After merging of the two main databases, we obtain an unbalanced panel database of 122,621 observations (excluding outliers) from 34,941 firms for the period 2005-10. ${ }^{19}$

\subsection{The Netherlands}

For the empirical analysis for the Netherlands, we merge data from three main Dutch data sources: (i) the General Business Register (GBR); (ii) the Baseline database; and (iii) the International Trade Database, all provided by Statistics Netherlands into a panel data set covering the years $2002-10 .{ }^{20}$ The GBR is, in principle, exhaustive in the sense that it contains information about every firm in the Netherlands, including a set of basic firm characteristics such as the number of employees in fulltime equivalents and the sector in which the firm operates according to the internationally standardised ISIC Rev. 3.1 sector classification. ${ }^{21}$ Analogous to

\footnotetext{
${ }^{14}$ See Tamminen (2014) for further details on the Finnish data.

${ }^{15}$ Firms are classified into four groups: micro (less than 10 employees), small (10-49 employees), medium (50-249 employees) and large (at least 250 employees) firms according to the definitions of the European Union (see http://ec.europa.eu/en terprise/policies/sme/facts-figures-analysis/sme-definition/).

${ }^{16}$ The analysis excludes self-employed and other firms with less than four employees. Finnish tax legislation provides an incentive for owners of small firms to pay themselves very low salaries and artificially increase the pretax profits of the firm. This way they can obtain lower taxation on their income, since profits have been taxed less heavily than wages. This renders the profit information of the smallest firms difficult to compare with larger firms. However, most micro-firms have an equal incentive to do so which renders comparing domestic and exporting micro-firms still feasible.

${ }^{17}$ The procedure for the identification of each firm's export status in each year is explained in detail in Tamminen and Chang (2012).

${ }^{18}$ Firms classified to NACE, Rev.2 sectors from A to E are grouped to the manufacturing sectors class.

${ }^{19} \mathrm{We}$ focus on robust estimations in which the top and bottom $1 \%$ of the observations along the relevant distributions are excluded throughout the paper for both Finland and the Netherlands, in order to eliminate implausible observations due to measurement errors, which we are unable to further investigate due to confidentiality considerations.

${ }^{20}$ We confine ourselves to discussing some key characteristics of each data source in this section. See van den Berg (2014) for further details, also regarding the merging procedure of the data sets.

${ }^{21}$ The ISIC Rev. 3.1 sector classification equals the SBI'93 2 digit classification employed by Statistics Netherlands.
} 
the Finnish data, we eliminate firms with less than 4 employees from the analysis because comparable tax incentives apply to small firms in the Netherlands. We take from a related database information concerning the ultimate controlling institution of the firm being either Dutch or located abroad. The Baseline database contains a wealth of financial information collected from both corporate tax declarations and income tax declarations of entrepreneurs, which is merged to the GBR. The Baseline database contains information about profits, gross output, value added and the value of capital, labour and intermediate inputs, which are transformed using separate sector-level price indices. Because of their fundamentally different nature, we separate the data into two main sectors, manufacturing, and wholesale \& retail trading sectors. $^{22}$ Trade data are taken from the International Trade database and include information on all imports and exports of goods by Dutch firms. Extra-EU trade is recorded by the Customs Authority and intra-EU imports, and exports are recorded by the Dutch Tax Authority. The trade data available at the firm level covers more than $80 \%$ of annual aggregate trade in terms of value in the Netherlands. ${ }^{23}$ The merging procedure results in an unbalanced panel data set containing a total of 501,769 observations of 139,160 firms spanning a period of nine years $(2002-10) .^{24}$

\section{5 | EMPIRICAL METHOD}

\section{1 | Measuring profitability}

There are, of course, several ways to measure profitability empirically. Although some business people are interested in analysing profit margins per employee, ${ }^{25}$ most investors use indicators based on margins and returns from financial statements to assess the performance and attractiveness of a firm as an investment (Robinson et al., 2012). ${ }^{26} \mathrm{We}$ concentrate our analyses on gross profit margins and net profit margins as these are the indicators most directly related to the theoretical expectations derived in Section 3. ${ }^{27}$

\footnotetext{
${ }^{22}$ We focus the analysis of Dutch firms on manufacturing and wholesale \& retail trading, thereby excluding service sectors, since data regarding trade in services are not yet sufficiently available for the Netherlands. We choose financial intermediation as the cut-off point for service sectors, which corresponds to ISIC Rev. 3.1 section J, division 65. Manufacturing sectors correspond in the analysis to ISIC Rev. 3.1 sections A through I, excluding G. Wholesale \& retail traders correspond to ISIC Rev. 3.1 section G. The OECD and Eurostat recommend to define manufacturing as sections A through $\mathrm{F}$ and to include section $\mathrm{G}$ to $\mathrm{Q}$ in services. However, in terms of goods trade this division is less sensible, since a considerable part of goods trade takes place in trade and transport sectors. It is therefore more appropriate to separate these sections from typical (financial and public) service sectors.

${ }^{23}$ The trade data are recorded on VAT numbers. Connection to the firm identification key used by Statistics Netherlands leads to a merging loss of about $20 \%$ of annual trade values.

${ }^{24}$ This is after eliminating four sectors with eight observations or less, micro-firms (less than four fulltime equivalents) and implausible observations with zero or negative output or exports exceeding gross output.

${ }^{25} \mathrm{https} / / / \mathrm{www} . \mathrm{mckinsey} \cdot \mathrm{com} /$ business-functions/strategy-and-corporate-finance/our-insights/the-new-metrics-of-corporate-performance-profit-per-employee

${ }^{26}$ They may also use indicators defined per dividend or per share, but most of the data we have available do not include that kind of information.

${ }^{27}$ We have done sensitivity analyses by analysing also returns on assets ROA, measured by net profit level divided by the value of assets, and gross profits per employee (GPE) in a similar way as gross profitability GP and net profitability NP. The ROA and GPE analyses return relatively similar conclusions on the relationship between internationalisation status, profit margins and productivity and therefore their results are not presented here. These results can be obtained from the authors upon request.
} 
If we have information on the firm's revenue $R$ and its variable costs $V C$, we can measure the gross profit level $\pi_{G}$ as the difference between $R$ and $V C$ and the gross profit margin $G P M$ as the ratio of this relative to $R$; see Equation (4). ${ }^{28}$ If we know the fixed cost of production $F C$ and the fixed costs for exporting $F C_{x}$ (which is zero for domestic firms), we can calculate the net profit margin $N P M$; see Equation (5).

$$
\begin{gathered}
G P M=\frac{\pi_{G}}{R}=\frac{R-V C}{R}, \\
N P M=\frac{\pi_{N}}{R}=\frac{R-V C-F C-F C_{x}}{R} .
\end{gathered}
$$

\section{2 | Empirical methodology}

The empirical analysis focuses on the relation between export status, productivity and profitability using robust pooled OLS panel regressions (see Equation 6) to test the hypotheses derived from the theoretical models. The empirical evidence suggesting that highly productive firms self-select into exporting is compelling (Wagner, 2012b). This implies that there is the threat of endogeneity arising in a regression of profitability on export status, due to sample selection bias. As a robustness test, we also estimate fixed effects panel regressions to control for unobserved firm-specific heterogeneity. However, in the fixed effects regressions the relationship between trade status and profitability only reflects the relation between the two variables for the subset of firms that switch trade status in the observed time frame, substantially reducing the number of usable observations. We therefore only briefly discuss the firm fixed effect results in Section 6 and report details in an Appendix S1 available upon request.

The panel regression model is of the form:

$$
\left(\frac{\pi_{X i j t}}{R_{i j t}}-\frac{\pi_{X j t}}{R_{j t}}\right)=\alpha+Y_{i j t}^{\prime} \beta_{1}+\varphi_{i j t} \beta_{2}+\left(Y_{i j t} \times \varphi_{i j t}\right)^{\prime} \beta_{3}+Z_{i j t}^{\prime} \gamma+\epsilon_{i j t},
$$

where $\frac{\pi_{X j i t}}{R_{i j t}}$ refers to profit margin $\pi_{X}$ of firm $i \in I$ from sector $j \in J$ in year $t \in T$ relative to sector $j$ 's mean profit margin over sales $\frac{\pi_{X j t}}{R_{j t}} ; Y_{i j t}$ refers to a matrix of dummy variables for the trade status of the firm ${ }^{29}$; $\varphi_{i j t}$ refers to (the log of) labour productivity (defined as value added per employee) ${ }^{30}$ and $Y_{i j t} \times \varphi_{i j t}$ refers to a set of interaction terms between trade status and productivity. Non-trading firms are the reference group, implying that $\alpha$ captures the correlation between being a non-trader and profitability. The relation between trade status and profitability thus depends on $\beta_{1}, \beta_{3}$, and productivity (see Equation 7):

$$
\partial \frac{\left(\frac{\pi_{X i j t}}{R_{i j t}}-\frac{\pi_{X j t}}{R_{j t}}\right)}{\partial Y}=\beta_{1}+\varphi_{i j t} \times \beta_{3} .
$$

The matrix of control variables $Z_{i j t}$ includes the export share in total sales, a dummy for exporters during the years of the Great Recession from 2008 to 2009 (exports declined significantly

\footnotetext{
${ }^{28}$ Only the cost of capital is considered a fixed cost in the short run; all other cost categories are considered variable.

${ }^{29}$ Instead of using dummy variables, as is standard in the literature, Fryges and Wagner (2010) analyse export intensity and profitability and find a non-linear relationship, particularly at the extremes. Note that we control for export shares (and import status) in our regressions in Section 6.

${ }^{30}$ With the Dutch data, we are able to also run the regressions with total factor productivity (TFP) instead of labour productivity to control for the sensitivity of the results with regard to the productivity measure included. The regression results were not significantly different between the two productivity measures.
} 
during these years and this has been found to affect also exporters' profitability significantly), (the $\log$ of) firm size in terms of employment, and a dummy variable indicating whether the firm is a multinational/under foreign control. ${ }^{31}$ In addition, we control for the (log of the) capital-labour ratio measured by the book value of total assets over employment. This variable is expected to be an important determinant of profitability. However, due to suspected endogeneity with other explanatory variables (such as with the multinational dimension), we include this variable to the model in a stepwise fashion.

Albuquerque (2009) argues that size- and industry-specific groups provide the best view on the comparative performance of firms, since business cycles are mostly industry specific and firm size significantly affects the firm's ability to respond to shocks. Therefore, a full set of industry and year-specific dummy variables have been included in the control variables. In addition, since investors generally require a risk premium for financing start-ups, we would like to control for the age of the firm. Unfortunately, this information is not available. However, the included control variable for firm size typically correlates with firm age. Finally, $\epsilon_{i j t}$ denotes the error term.

Due to the expected sample selection bias, it is difficult to identify a fully exogenous instrument for export status. To deal with this problem, and in line with existing literature (Greenaway \& Kneller, 2007), we employ propensity score matching (PSM) to investigate if export starters convert to a different profitability growth path relative to continuing non-exporters. The disadvantage of this procedure is that it only allows us to test Hypothesis III and not Hypothesis I or II. For brevity, we therefore only briefly discuss the propensity score matching results in Section 6 and report details of the matching procedure and result in the Appendix available upon request.

\section{6 | EMPIRICAL FINDINGS}

The results presented in this section are based on separate analyses of the data sets concerning Finland and the Netherlands. The available number of observations is about four times larger for the Netherlands than for Finland, namely about 500,000 vs. 120,000 observations. This can be explained by the relative size of both economies and the fact that the panel regarding the Netherlands includes three more years (2002-10 compared to 2005-10). For both countries, the number of observations declines as firm size rises, such that the majority of observations is for micro-firms (ranging from $42 \%$ to $65 \%$ ) and for small firms (ranging from $32 \%$ to $44 \%$ ). Taken together, the micro-firms and small firms account for at least $86 \%$ of the observations in Finland and $94 \%$ in the Netherlands. The lower number in Finland reflects the fact that the share of medium-sized firms is about twice as high as in the Netherlands $(10.0 \%$ vs. $4.3 \%)$ and the share of large firms is about six times as high $(2.6 \%$ vs. $0.4 \%)$.

Figure 5 presents the share of firms that are exporting by size class. Although at the macrolevel the Dutch economy is more trade-oriented than the Finnish economy, it is well known that at the micro-level the export involvement of Dutch firms is relatively low in an international perspective (Mayer \& Ottaviano, 2008). In addition, the share of exporting firms rises monotonically in firm size for both countries. Figure 5 shows that in Finland the share of firms that exports rises from about $28 \%$ for micro-firms to $73 \%$ for large firms, with an economy-wide average of about

\footnotetext{
${ }^{31}$ In the Dutch data, the dummy variable indicating whether a firm is ultimately controlled by a foreign company is not derived from the underlying ownership structure, and it indicates whether the controlling institution is effectively located abroad. For Finland, we control for whether the firm is a multinational or not. A firm is classified as multinational if it has a subsidiary abroad or if it is classified as foreign firm or foreign subsidiary to the tax authorities.
} 


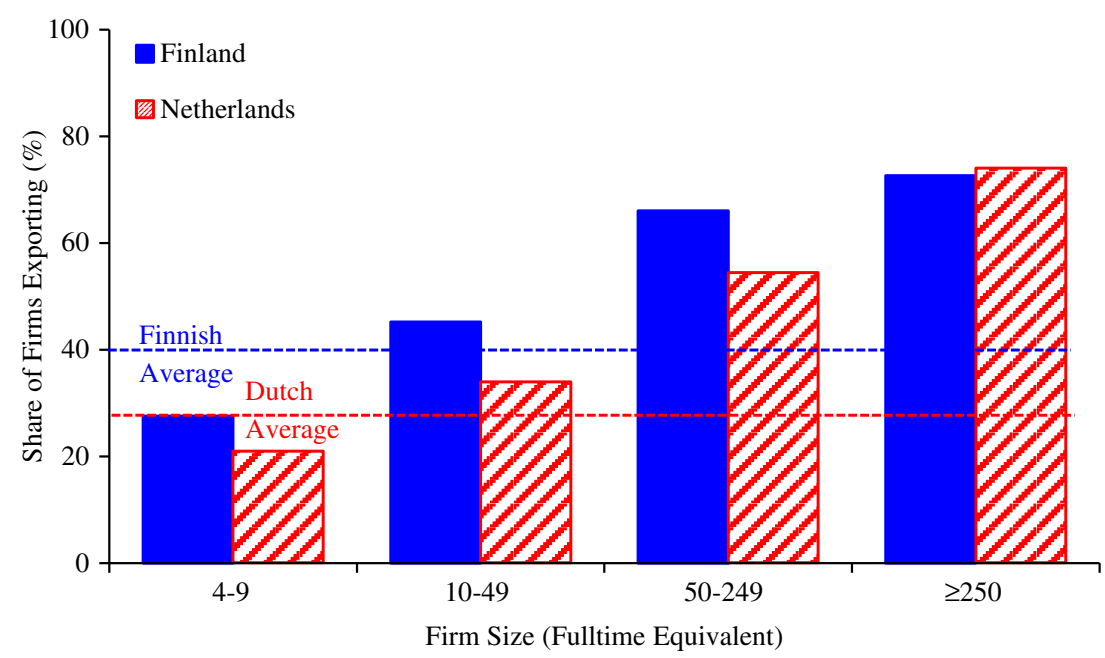

FIGURE 5 Share of firms exporting (\%) [Colour figure can be viewed at wileyonlinelibrary.com]

$40 \%$ of all firms exporting. For the Netherlands, the share of firms exporting rises from about $21 \%$ for micro-firms (somewhat lower than in Finland) to $74 \%$ for large firms (which is about the same as in Finland), with an economy-wide average of about $27 \%$ of all firms exporting.

\section{1 | Trade and profit margins in Finland}

We start with an analysis of the relationship between trading firms and profit margins for Finland. Table 1 provides an overview of profit margins in Finland for different types of firms. Columns (1)-(4) analyse the manufacturing sectors, and columns (5)-(8) analyse the service sectors. Columns (1), (2), (5) and (6) focus on net profit margins and the other columns focus on gross profit margins. All regressions control for sector-year fixed effects, export share, firm size (measured in log employment), foreign ownership (multinational dummy) and an exporter dummy variable in 2008-9. In addition, the even columns (2), (4), (6) and (8) control for capital intensity (measured in $\log$ of capital-labour ratio). ${ }^{32}$

Non-trading firms are the reference group in all regressions. For the manufacturing sectors, we identify three more types of firms: (i) only exports; (ii) only imports; and (iii) two-way traders. This gives us six estimated coefficients on the link between trade and either net profit margins or gross profit margins (three without and three with a control for capital intensity). For the service sectors, we identify two firm types in addition to non-traders, namely (i) only imports and (ii) services exporters. ${ }^{33}$ This gives us four estimated coefficients on the link between trade and either net

\footnotetext{
${ }^{32}$ As a robustness test, we estimate firm fixed effects panel regressions to control for unobserved firm-specific heterogeneity. However, in the firm fixed effects specifications the relationship between trade status and profitability only reflects the correlation between the two variables for the subset of firms that switch trade status in the observed time frame. Therefore, the results in Tables 1 and 2 are our preferred specification bearing our hypotheses in mind. The results of the firm fixed effects regressions do not differ notably from the results in Tables 1 and 2, as briefly discussed in Section 6.

${ }^{33}$ Only imports refer to firms that import from EU area, but do not export at all. Services exporters refer to service sector firms doing exports. Some of them are two-way traders, but valid identification of non-EU (service) imports is not available in the data. Therefore, two-way traders are not separated from pure exporters.
} 
T A B L E 1 Profit margins in Finland (OLS panel regressions, 2005-10)

\begin{tabular}{|c|c|c|c|c|c|c|c|c|}
\hline & \multicolumn{4}{|c|}{ Manufacturing sectors } & \multicolumn{4}{|c|}{ Service sectors } \\
\hline & \multicolumn{2}{|c|}{ Net profit margin } & \multicolumn{2}{|c|}{ Gross profit margin } & \multicolumn{2}{|c|}{ Net profit margin } & \multicolumn{2}{|c|}{ Gross profit margin } \\
\hline & 1 & 2 & 3 & 4 & 5 & 6 & 7 & 8 \\
\hline Non-trader & Reference & group & & & & & & \\
\hline Only exports & $\begin{array}{l}-0.096 \\
(-1.74)\end{array}$ & $\begin{array}{l}-0.036 \\
(-0.60)\end{array}$ & $\begin{array}{c}-0.142^{*} \\
(-2.41)\end{array}$ & $\begin{array}{c}-0.143 * \\
(-2.08)\end{array}$ & & & & \\
\hline Only imports & $\begin{array}{r}-0.107 * * \\
(-2.63)\end{array}$ & $\begin{array}{l}-0.086 \\
(-1.78)\end{array}$ & $\begin{array}{r}-0.119 * * \\
(-3.09)\end{array}$ & $\begin{array}{c}-0.098 * \\
(-2.21)\end{array}$ & $\begin{array}{c}-0.115^{*} \\
(-2.01)\end{array}$ & $\begin{array}{l}-0.055 \\
(-1.00)\end{array}$ & $\begin{array}{l}-0.035 \\
(-0.81)\end{array}$ & $\begin{array}{l}-0.031 \\
(-0.61)\end{array}$ \\
\hline 2-way trader & $\begin{array}{r}-0.094 * * \\
(-2.60)\end{array}$ & $\begin{array}{l}-0.061 \\
(-1.43)\end{array}$ & $\begin{array}{r}-0.119 * * * \\
(-3.43)\end{array}$ & $\begin{array}{r}-0.106^{* *} \\
(-2.67)\end{array}$ & & & & \\
\hline Service exp & & & & & $\begin{array}{r}-0.128 * * * \\
(-3.36)\end{array}$ & $\begin{array}{r}-0.107 * \\
(-2.34)\end{array}$ & $\begin{array}{r}-0.170 * * * \\
(-3.64)\end{array}$ & $\begin{array}{r}-0.114 * \\
(-2.23)\end{array}$ \\
\hline productivity & $\begin{array}{r}0.056 * * * \\
(26.76)\end{array}$ & $\begin{array}{r}0.062 * * * \\
(22.48)\end{array}$ & $\begin{array}{r}0.051 * * * \\
(25.37)\end{array}$ & $\begin{array}{r}0.052 * * * \\
(20.36)\end{array}$ & $\begin{array}{r}0.068 * * * \\
(32.72)\end{array}$ & $\begin{array}{r}0.073 * * * \\
(23.54)\end{array}$ & $\begin{array}{r}0.065 * * * \\
(26.34)\end{array}$ & $\begin{array}{r}0.071 * * * \\
(18.82)\end{array}$ \\
\hline
\end{tabular}

Interaction terms with productivity

\begin{tabular}{lrrrrrrrr} 
Only exports & 0.009 & 0.003 & $0.012 *$ & 0.013 & & & & \\
& $(1.62)$ & $(0.58)$ & $(2.15)$ & $(1.9)$ & & & & \\
\hline Only imports & $0.009 *$ & 0.008 & $0.011^{* *}$ & $0.009 *$ & 0.01 & 0.004 & 0.003 & 0.002 \\
& $(2.39)$ & $(1.63)$ & $(2.97)$ & $(2.14)$ & $(1.76)$ & $(0.78)$ & $(0.62)$ & $(0.49)$ \\
\hline 2-way & 0.007 & 0.004 & $0.009 * *$ & $0.008 *$ & & & & \\
trading & $(1.91)$ & $(1.04)$ & $(2.73)$ & $(2.19)$ & & & & \\
\hline Service exp & & & & & $0.010 * *$ & $0.009 *$ & $0.014 * *$ & 0.009 \\
& & & & & $(2.8)$ & $(2.02)$ & $(3.05)$ & $(1.81)$
\end{tabular}

Wald test - H0: Coefficients of labour productivity + labour productivity $\times$ trade status $>0$

\begin{tabular}{|c|c|c|c|c|c|c|c|c|}
\hline Only exports & 1.000 & 1.000 & 1.000 & 1.000 & & & & \\
\hline $\begin{array}{l}\text { 2-way } \\
\text { trading }\end{array}$ & 1.000 & 1.000 & 1.000 & 1.000 & & & & \\
\hline Service exp & & & & & 1.000 & 1.000 & 1.000 & 1.000 \\
\hline $\begin{array}{l}\text { No. of } \\
\text { observations }\end{array}$ & 51,249 & 39,284 & 51,073 & 39,091 & 58,360 & 45,288 & 57,943 & 44,911 \\
\hline$R^{2}$ & .292 & .312 & .224 & .232 & .307 & .315 & .207 & .206 \\
\hline
\end{tabular}

Notes: All regressions include (not shown) as additional controls: sector-year fixed effects, exporter 2008-9 dummy, export share, firm size (ln) and multinational dummy; columns (2), (4), (6) and (8) in addition control for capital-labour ratio (ln). Productivity is measured as the log of labour productivity.

$*, * *, * * *$ Statistically significant at $5 \%, 1 \%$ and $0.1 \%$ levels; $t$-statistics in (.).

profit margins or gross profit margins (two without and two with a control for capital intensity). Table 1 also reports the interaction between trading type and productivity.

We start with a discussion of hypotheses I and II on the relationship between productivity and profit margins for domestic and trading firms. Regarding Hypothesis I on domestic firms, 
for all eight regressions, profit margins rise significantly as productivity rises for domestic firms. This supports Hypothesis I of the Melitz model and contradicts the Egger-Kreickemeier model.

Regarding Hypothesis II on trading firms, based on the results from Hypothesis I, profit margins also rise with productivity for trading firms, unless the interaction between trading type and productivity would be sufficiently strong and negative to overturn this outcome. This is not the case. Either the interaction term of trade type and productivity is not significant (in 11 cases, namely 6 for manufacturing and 5 for services) or it is significantly positive (in 9 cases, namely 6 for manufacturing and 3 for services), thus strengthening rather than weakening the link between profit margins and productivity for trading firms. This provides support for both the Melitz model and the Egger-Kreickemeier model.

We now turn to Hypothesis III on the profit margins of trading relative to non-trading firms. This hypothesis is supported if the estimated impact of trade type is either not significant or statistically significantly negative. All estimated coefficients meet this requirement and thus provide strong support for the Egger-Kreickemeier model. More specifically, for gross profit margins all six coefficients in manufacturing are significantly negative, compared with two in services (in addition to two coefficients that are not significant). Regarding net profit margins, five coefficients are significantly negative ( 2 for manufacturing and 3 for services) and five coefficients are not significant (4 for manufacturing and 1 for services).

\subsection{Trade and profit margins in The Netherlands}

We continue with an analysis of the relationship between trading firms and profit margins for the Netherlands; see Table 2. The organisation of the table is similar, with the same control variables for each regression, non-trading firms as the reference group, columns (1)-(4) for manufacturing sectors, and columns (1), (2), (5) and (6) focusing on net profit margins while the other columns report on gross profit margins. The main differences are that we report results for wholesale \& retail trade instead of service sectors in columns (5)-(8) and are able to identify the same type of trading firms in all columns, namely only exports, only imports and two-way trader. There are thus six estimated coefficients on the link between trade and either net profit margins or gross profit margins (three firm types without and with controlling for capital intensity) for both manufacturing sectors and wholesale \& retail trade.

Regarding Hypothesis I on productivity and profit margins for domestic firms, the results for the Netherlands are identical to those of Finland: for all eight regressions, profit margins rise significantly as productivity rises for domestic firms. This supports Hypothesis I and contradicts the Egger-Kreickemeier model.

Regarding Hypothesis II on productivity and profit margins for trading firms: the results for the Netherlands are the same as in Finland for manufacturing sectors and slightly different (but leading to the same conclusion) for wholesale \& retail trade. More precisely, for the manufacturing sectors the interaction terms of productivity and trading type are either not significant (in one case) or statistically significantly positive (in 11 cases), thus reinforcing the link of Hypothesis I between productivity and trading type (as in Finland). For the wholesale \& retail sector, the interaction results are mixed: five coefficients are not significant (all 4 coefficients for only imports and 1 coefficient for two-way traders), three coefficients are significantly positive (and thus reinforce the direction of Hypothesis II, all of these are for two-way traders), and four coefficients are significantly negative (all 4 coefficients for only exports). Since the significantly neg- 


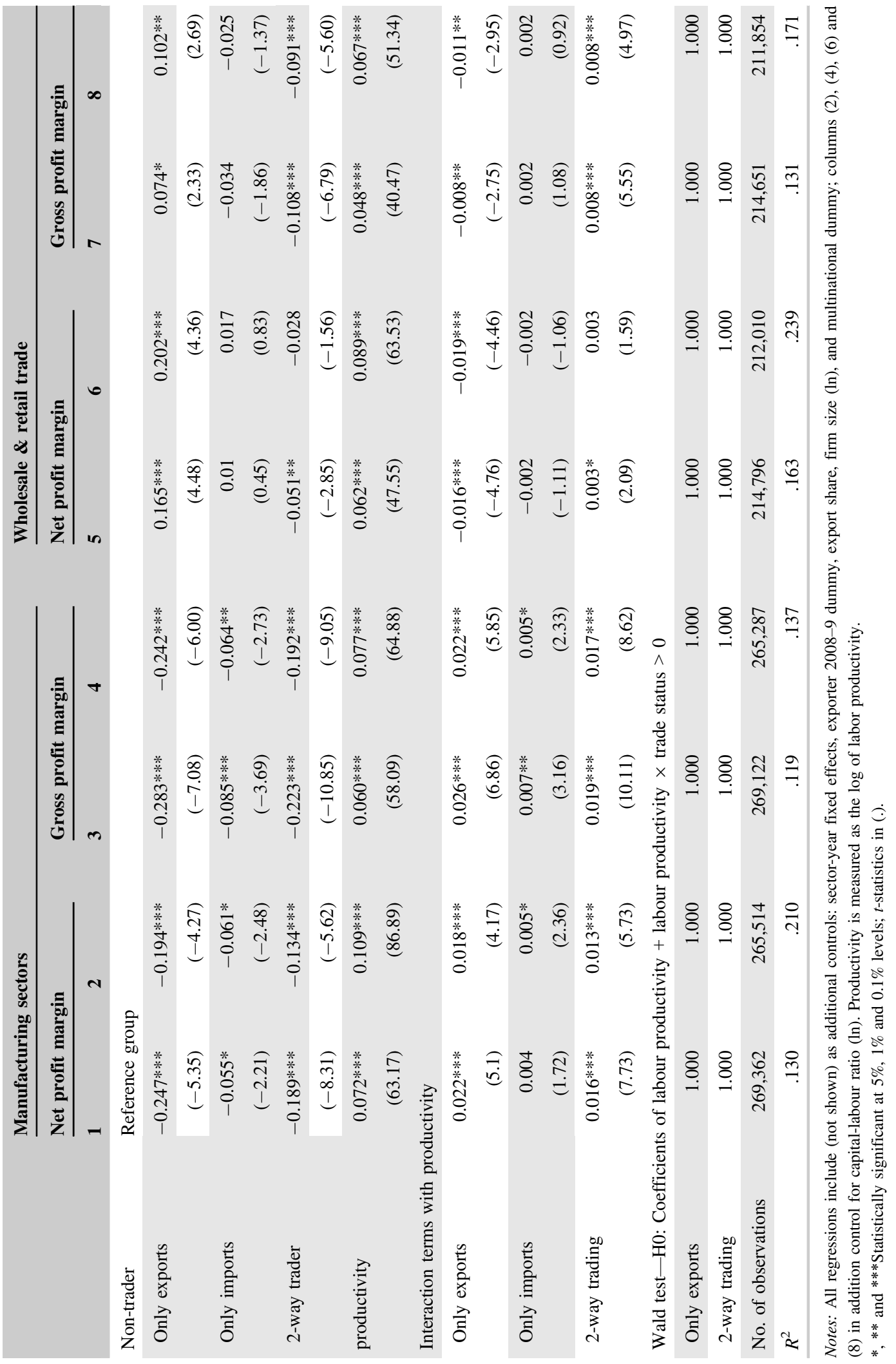


ative coefficients are not strong enough to overturn the general connection between productivity and profit margins, we still arrive at the same conclusion: for all trading firm types profit margins rise as productivity rises. This provides support for both the Melitz model and the EggerKreickemeier model.

Finally, we turn to Hypothesis III on the profit margins of trading relative to non-trading firms for the Netherlands. Here, the results are both stronger and weaker than in Finland. The results are stronger in the Netherlands in the manufacturing sector where all 12 estimated coefficients are significantly negative for both gross profit margins and net profit margins: trading firms thus have a profit margin disadvantage relative to domestic firms, in accordance with Hypothesis III and in support of the Egger-Kreickemeier model. The results are weaker in the Netherlands in the wholesale \& retail trade sector. More specifically, they are in line with the findings in Finland for only importers and two-way traders, where the estimated coefficients are either not significant (in five cases) or significantly negative (in three cases). They are reversed, and thus in contradiction to Hypothesis III, for only exporters, where all four estimated coefficients are significantly positive, indicating higher profit margins for only exporters than for domestic firms, in contrast to the Egger-Kreickemeier model.

Figure 6 summarises the findings on Hypothesis III for both Finland and the Netherlands. The strongest support is for manufacturing sectors in the Netherlands, where all estimated coefficients are significantly negative for all profit margins. The same holds for the gross profit margin for manufacturing sectors in Finland. Somewhat weaker support, but all results still in line with Hypothesis III are provided by the net profit margin for manufactures in Finland, by the service sector in Finland, and by only importers and two-way traders for wholesale \& retail trade in the Netherlands. The only exception to Hypothesis III is thus provided by only exporters in wholesale $\&$ retail trade in the Netherlands.

(a)

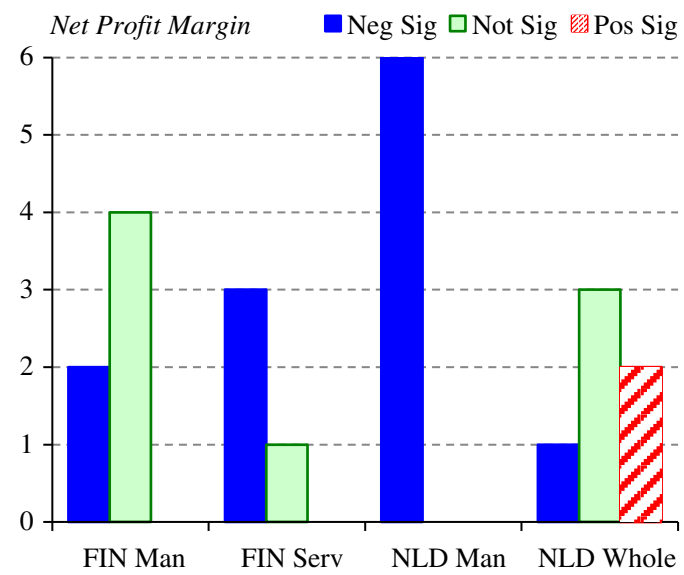

(b)

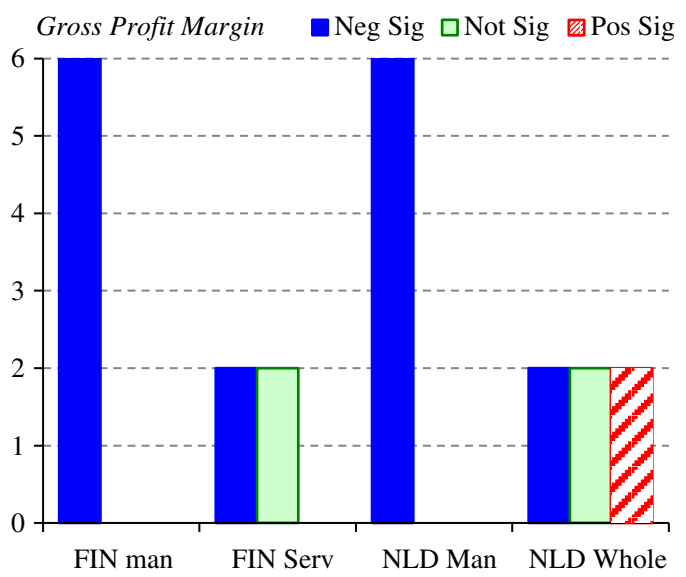

FIGURE 6 Overview of profit margins and trading firms

Source: Tables 1 and 2; overview of coefficients for all types of trading firms; neg sig = negative significant; not sig = not significant; pos sig = positive significant; significance at $10 \%$ or better; man = manufacturing; serv $=$ services exporter; whole $=$ wholesale $\&$ retail trade; FIN $=$ Finland; NLD $=$ Netherlands; all positively significant coefficients are related to only exporters in wholesale \& retail trade [Colour figure can be viewed at wileyonlinelibrary.com] 


\section{3 | Summary, firm fixed effects and propensity score matching}

\subsection{1 | Summary}

We analyse hypotheses I-III for domestic firms and three different types of trading firms for manufacturing sectors in Finland and the Netherlands, service sectors in Finland, and wholesale \& retail trade in the Netherlands in Tables 1 and 2, together representing 11 different cases (which are tested 44 times). ${ }^{34} \mathrm{We}$ find (strong) support for all hypotheses:

- Hypothesis I is supported in all cases: profit margins rise as productivity rises for domestic firms; this is in line with the Melitz model and contradicts the Egger-Kreickemeier model.

- Hypothesis II is supported in all cases: profit margins rise as productivity rises for trading firms; this is in line with both the Melitz model and the Egger-Kreickemeier model.

- Hypothesis III is supported in almost all cases (10 of 11 cases or 40 of 44 tests): profit margins for trading firms are lower than for domestic firms or not significantly different. The only exception is for exporting firms in the Dutch wholesale \& retail sector. This is in line with the Egger-Kreickemeier model.

\subsection{2 | Firm fixed effects}

As already pointed out in Section 5, the main disadvantage of the firm fixed effects results is that only firms that switch trade status are included in the analysis. Detailed results are provided in the Appendix available upon request. The conclusion for Hypothesis $I$ is the same as above: in all cases profit margins rise as productivity rises for domestic firms, in line with the Melitz model. Similarly, the conclusion for Hypothesis II is the same as above: in all cases profit margins rise as productivity rises, in line with both the Melitz and the Egger-Kreickemeier model. The results for Hypothesis III are also similar: profit margins for trading firms are lower than for domestic firms or not significantly different for all but 5 (instead of 4 ) tests. ${ }^{35}$

\subsection{3 | Propensity score matching}

The propensity score matching analysis is described in more detail in the Appendix available upon request. In total, we analyse 212 different "cases" (64 for Finland and 148 for The Netherlands), where a "case" represents a comparison of the performance of the number of firms that started exporting in a given year for a particular type of sector compared to a similar group of matched firms, both in gross and net profit margins and both in levels and growth rates. The overwhelming majority of cases (198 cases or $93.4 \%$ of the total) have no difference between export starters and the control group. In 11 cases (5.2\% of the total), export starters had higher profit margins, and in three cases (1.4\% of the total), export starters had lower profit margins. Since the latter percentages clearly fall in the margin of error, we conclude that export starters do not have higher profit margins than continuing non-exporters (providing further support for Hypothesis III).

\footnotetext{
${ }^{34}$ Since we analyse both net profit margins and gross profit margins, as well as with and without controlling for capitallabour ratios, the 11 cases are in total evaluated 44 times.

${ }^{35}$ Mostly related to net profit margins for the Dutch wholesale \& retail trade sector.
} 


\section{7 | THEORETICAL IMPLICATIONS}

What do our empirical findings regarding hypotheses I-III imply for the models we analyse in Section 3? A clear shortcoming of the Egger-Kreickemeier model is that there is no positive relationship between firm productivity and profit margins for domestic firms (see Figure 3), which contradicts the empirical evidence provided for Hypothesis I. The absence of a positive relationship is based on two main aspects of the theoretical model: ${ }^{36}$ first, the determination of the number of firms, and second, the determination of wages based on a fair-wage bargaining system. We briefly discuss both aspects in turn.

Regarding the first aspect, the decision to become a manager and start a firm is based on an individual's managerial ability $\varphi$ and associated (domestic) firm profits $\pi_{d}(\varphi)$, relative to that individual's earning capacity as a production worker, which is equal to the probability of finding a job $1-U$, where $U$ is the unemployment rate, times the average wage rate of production workers $\bar{w}$, as unemployment benefits are set equal to zero. Since there are no fixed costs for domestic firms, the profits are equal to the operating profits, which is $1 / \sigma$ times domestic firm revenue $r_{d}(\varphi)$. The number of firms is determined by the condition that the profit level of the marginal manager with ability $\varphi_{d}^{*}$ is equal to the expected income of a production worker: $\pi_{d}\left(\varphi_{d}^{*}\right)=(1-U) \bar{w}$.

Regarding the second aspect, higher productivity firms pay higher wages based on a fair-wage bargaining system; see Akerlof and Yellen (1990). Workers condition their effort $\varepsilon$ on the wage they consider to be "fair," denoted by $\hat{w}$, which depends on: (i) an external point of reference; and (ii) the economic performance of the firm they work for. If the actual wage they receive is higher than the fair wage, they provide normal effort (normalised to 1); otherwise effort decreases proportionally with the actual wage relative to the fair wage. In the Egger-Kreickemeier specification, the external point of reference is the expected labour income per worker $(1-U) \bar{w}$, the economic performance of the firm is measured by the operating profits $r_{d}(\varphi) / \sigma$, and the fair wage specification $\hat{w}$ for a domestic firm with productivity $\varphi$ is given by: $\hat{w}(\varphi)=\left(r_{d}(\varphi) / \sigma\right)^{\theta}((1-U) \bar{w})^{1-\theta}$, where $\theta \in(0,1)$ is a rent sharing parameter. In equilibrium, all firms will pay the fair wage and all workers will supply normal effort. Moreover, if we compare two firms with productivity levels $\varphi_{1}$ and $\varphi_{2}$, then the wage rates and the revenue levels rise as a power function of $\varphi_{1} / \varphi_{2}$, which in combination with assuming a Pareto productivity distribution makes it possible to solve the model analytically.

Can we adjust either of the two main aspects of the model to incorporate rising profit margins as productivity rises for domestic firms? We answer this question in reverse order, starting with the fair wage bargaining system and then turning attention to the determination of the number of firms.

In the Egger-Kreickemeier model, more productive firms pay higher wages at the rate $\varphi^{\theta}$. The speed at which wage rates rise as productivity rises in markets with heterogeneous firms is, of course, an empirical matter; see, for example, Bastos, Monteiro, and Straume (2009). Perhaps it is not a power function. Perhaps it reaches some (time varying) finite upper bound, or it is an $S$-type function. We can, of course, complicate the fair-wage bargaining system to reflect these empirical findings, for example, by using a different equation to determine the fair wage (such as CES), or by measuring the external reference or economic performance relative to a non-zero fixed reference point (such as $a+r_{d}(\varphi) / \sigma$ ), or by using a different reference point, or a different measure of economic performance. The important thing to note is that, as long as we do not adjust the

\footnotetext{
${ }^{36}$ It is, of course, also based on iso-elastic demand for intermediates. We take this for granted here, as it is the basis of most work on heterogeneous firms and it is also used in the Melitz model.
} 
first aspect of the model for determining the number of firms, none of these complications is going to have an effect on the profit margin of firms, which is what we are interested in this paper. Why is that? In this model, unit costs are equal to $w_{\varphi} / \varphi \varepsilon_{\varphi}$, where $w_{\varphi}$ is the wage rate paid by a firm with productivity $\varphi$ and $\varepsilon_{\varphi}$ is the labour effort of workers. In equilibrium, labour effort will be 1 , so unit costs are simply $w_{\varphi} / \varphi$. Any adjustment of the fair wage bargaining system may change the speed at which wage rates rise as productivity rises. This will, of course, affect the speed at which the firm price changes as productivity changes, since prices are a constant markup over marginal costs. It will also affect the speed at which revenue rises as productivity rises. However, it does not affect the profit margin for domestic firms, which is equal to the operating profits $r_{d}(\varphi) / \sigma$ relative to revenue, and therefore equal to $1 / \sigma$ no matter at what speed wage rates and prices change.

Can we adjust the first aspect of the model, the determination of the number of firms, to allow for Hypothesis I? Yes, that is actually quite straightforward. All we have to do is to incorporate a fixed cost $f_{d}$ for operating a domestic firm. Individuals can still determine whether or not to become manager relative to earning capacity as a production worker, so the condition for determining the number of firms remains $\pi_{d}\left(\varphi_{d}^{*}\right)=(1-U) \bar{w}$. This time, however, firm profits are operating profits minus fixed costs $f_{d}$, so the profit margin is $(1 / \sigma)-f_{d} / r_{d}(\varphi)$, which rises as productivity rises. Note that for the marginal manager the profit margin is strictly positive, since $\frac{\pi_{d}\left(\varphi_{d}^{*}\right)}{r_{d}\left(\varphi_{d}^{*}\right)}=\frac{(1-U) \bar{w}}{r_{d}\left(\varphi_{d}^{*}\right)}>0$. The consequences of this adjusted Egger-Kreickemeier model are illustrated in Figure 7. At the viability cut-off level $\varphi_{d}^{*}$ the profit margin is strictly positive at point A. It then rises monotonically until the export cut-off level $\varphi_{x}^{*}$ is reached, at which point there is a discrete jump in the profit margin from point $\mathrm{B}$ to point $\mathrm{C}$, which under the conditions of the model is strictly below point A. After that, profit margins start to rise again until they reach the level $1 / \sigma$ asymptotically.

Figure 7 also illustrates the main disadvantage of this adjusted Egger-Kreickemeier model: the profit margins of domestic relative to exporting firms behave exactly as in the Melitz model. This implies that Hypothesis III (profit margins for domestic firms are at least as high as for trading firms) no longer holds and the implications of the adjusted Egger-Kreickemeier model are exactly the same as for the Melitz model. As we did at the end of Section 3 for the Melitz model, pointing out the large mass of both domestic and exporting firms in the neighbourhood of the export cutoff productivity level illustrated in Figure 4, we can then argue that we should not be surprised to see that profit margins are lower for exporting firms than for domestic firms, but this remains an empirical question and both models (adjusted Egger-Kreickemeier and Melitz) are not falsifiable on the basis of our strong support for Hypothesis III.

Would other theoretical models with firm heterogeneity then explain our empirical results? For example, Melitz and Ottaviano (2008) and Bernard, Eaton, Jensen, and Kortum (2003) present models with heterogeneous firms and endogenous markups, both including the theoretical expectation that markups of price over marginal costs rise along with firms' productivity. However, neither directly addresses the expected profit margin differences between domestic and exporting firms. ${ }^{37}$ These findings stress the need for further research on ways to reconcile theory and empirics on this matter.

\footnotetext{
${ }^{37}$ While, for example, in the Melitz and Ottaviano (2008) model absolute markups are lower in larger markets, the average profit margins of industries $(\bar{\pi} / \bar{r})$ does not vary with market size (see p. 301 of the article). Exporters do face higher costs and lower markups in foreign markets, but the expected profit from exporting is positive. Therefore, profit margins, especially for the marginal exporter in comparison with serving only the domestic market, are not easily traceable from the model.
} 


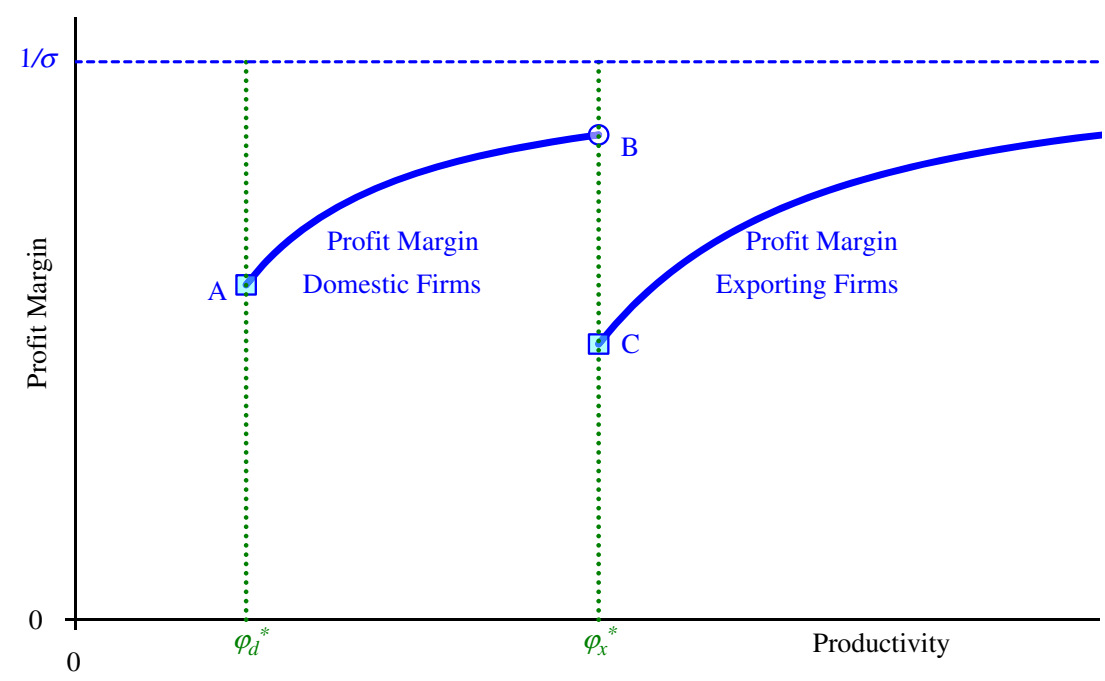

FIG URE 7 Profit margins in an adjusted Egger-Kreickemeier model [Colour figure can be viewed at wileyonlinelibrary.com]

\section{8 | CONCLUSION}

Compiling two parallel firm-level data sets covering Dutch firms over the years 2002-10 and Finnish firms over the years 2005-10, we investigate the relationship between trade status, productivity and profitability. We proceed in three steps. First, we analyse the predictions of two theoretical models (the Melitz model and the Egger-Kreickemeier model) regarding the relationship between profit margins and trade. This allows us to derive three testable hypotheses. Second, we empirically evaluate the three hypotheses for three types of trading firms and four types of sectors, for both gross profit margins and net profit margins.

Hypothesis I states that profit margins rise as productivity rises for domestic firms. The Melitz model supports this hypothesis, while the Egger-Kreickemeier model does not. Hypothesis II states that profit margins rise as productivity rises for trading firms. Both models support this hypothesis.

Finally, Hypothesis III states that profit margins are at least as high for domestic firms as for trading firms. The Egger-Kreickemeier model supports this hypothesis, while the Melitz model does not allow for any falsification in this respect.

We analyse hypotheses I-III for domestic firms and three different types of trading firms for manufacturing sectors in Finland and the Netherlands, service sectors in Finland and wholesale \& retail trade in the Netherlands, together representing 11 different cases. We find (strong) support for all hypotheses. Hypothesis I is supported in all cases; profit margins rise as productivity rises for domestic firms. This is in line with the Melitz model and contradicts the Egger-Kreickemeier model. Hypothesis II is also supported in all cases; profit margins rise as productivity rises for trading firms. This is in line with both the Melitz model and the Egger-Kreickemeier model.

Hypothesis III, finally, is supported in almost all cases (namely 10 of 11); the profit margin for domestic firms is at least as high as for trading firms. This supports the Egger-Kreickemeier model. Regarding the two theoretical models, we thus find: (i) support for the Melitz model in hypotheses I and II; and (ii) support for the Egger-Kreickemeier model in hypotheses II and III, but in contrast to Hypothesis I. 
We discuss the theoretical implications of our empirical analyses focusing on ways to adjust the Egger-Kreickemeier model to allow for Hypothesis I (profit margins rise for domestic firms as productivity rises). We argue that any attempt at accommodating Hypothesis I by adjusting the wage bargaining system is futile, since no modification of the model along this line will affect the profit margin of firms as long as we do not adjust the determination of the number of firms. Instead, it is straightforward to adjust the determination of the number of firms to accommodate Hypothesis I by incorporating a fixed cost for operating a domestic firm. However, we also argue that this adjusted Egger-Kreickemeier model comes at the expense of Hypothesis III (domestic firms are at least as productive as trading firms) no longer holding. In effect, regarding profit margins this adjusted model behaves exactly like the Melitz model. Further research is needed to reconcile theory and empirics on this matter.

\section{ACKNOWLEDGEMENTS}

Marcel van den Berg gratefully acknowledges funding from the Ministry of Economic Affairs and the Ministry of Foreign Affairs of the Netherlands. We thank Peter Neary, Peter van Bergeijk, participants at the 2013 annual conference of the European Trade Study Group, Birmingham, UK, seminar participants at VATT and the Finnish Labour Institute for Economic Research for valuable feedback and comments. The content of this publication does not reflect the official opinion of Statistics Netherlands or VATT. Responsibility for the information and views expressed in the paper lies entirely with the authors. Any remaining errors are our own.

\section{ORCID}

Marcel van den Berg (iD http://orcid.org/0000-0002-6172-9589

\section{REFERENCES}

Akerlof, G., \& Yellen, J. (1990). The fair wage-effort hypothesis and unemployment. Quarterly Journal of Economics, 105, 255-283. https://doi.org/10.2307/2937787

Albuquerque, A. (2009). Peer firms in relative performance evaluation. Journal of Accounting and Economics, 48 (1), 69-89. https://doi.org/10.1016/j.jacceco.2009.04.001

Andersson, M., Lööf, H., \& Johansson, S. (2008). Productivity and international trade: Firm level evidence from a small open economy. Review of World Economics, 144(4), 774-801. https://doi.org/10.1007/s10290-008-0169-5

Bastos, P., Monteiro, N. P., \& Straume, O. R. (2009). Firm heterogeneity and wages in unionised labour markets: Theory and evidence. Labour Economics, 16(4), 440-450. https://doi.org/10.1016/j.labeco.2008.12.004

Bausch, A., \& Krist, M. (2007). The effect of context-related moderators on the internationalization-performance relationship: Evidence from meta-analysis. Management International Review, 47(3), 319-347. https://doi.org/10. 1007/s11575-007-0019-z

Bernard, A., Eaton, J., Jensen, J., \& Kortum, S. (2003). Plants and productivity in international trade. The American Economic Review, 93(4), 1268-1290. https://doi.org/10.1257/000282803769206296

Bernard, A. B., Jensen, J. B., Redding, S. J., \& Schott, P. K. (2017). Global firms (NBER Working Paper 22727; commissioned for the Journal of Economic Literature). Retrieved from http://www.nber.org/papers/w22727

Bottazzi, G., Grazzi, M., Secchi, A., \& Tamagni, F. (2011). Financial and economic determinants of firm default. Journal of Evolutionary Economics, 21(3), 373-406. https://doi.org/10.1007/s00191-011-0224-6

Brakman, S., Garretsen, H., \& van Marrewijk, C. (2009). The new introduction to geographical economics. Cambridge, UK: Cambridge University Press. https://doi.org/10.1017/CBO9780511818745

Bridges, S., \& Guariglia, A. (2008). Financial constraints, global engagement, and firm survival in the United Kingdom: Evidence from micro data. Scottish Journal of Political Economy, 55(4), 444-464. https://doi.org/10.1111/ j.1467-9485.2008.00461.x 
Chang, H.-H., \& van Marrewijk, C. (2013). Firm heterogeneity and development: Evidence from Latin American countries. Journal of International Trade and Economic Development, 22(1), 10-51.

Clerides, S., Lach, S., \& Tybout, J. (1998). Is learning by exporting important? Micro-dynamic evidence from Colombia, Mexico, and Morocco Quarterly Journal of Economics, 113(3), 903-947. https://doi.org/10.1162/ 003355398555784

Egger, H., \& Kreickemeier, U. (2012). Fairness, trade, and inequality. Journal of International Economics, 86, 184196. https://doi.org/10.1016/j.jinteco.2011.10.002

Eriksson, T., Smeets, V., \& Warzynski, F. (2009). Small Open Economy Firms in International Trade: Evidence from Danish Transactions-level Data (Aarhus University Department of Economics Working Paper Series Working Paper 09-7, Aarhus University School of Business). Retrieved from https://www.researchgate.net/profile/ Tor_Eriksson/publication/46470094_Small_Open_Economy_Firms_in_International_Trade_Evidence_from_Danish_ Transactions-Level_Data/links/00b495268bddedbf9f000000.pdf

Fryges, H., \& Wagner, J. (2010). Exports and profitability: First evidence for German manufacturing firms. The World Economy, 33(3), 399-423. https://doi.org/10.1111/j.1467-9701.2010.01261.x

Girma, S., Görg, H., \& Strobl, E. (2004). Exports, international investment, and plant performance: Evidence from a non-parametric test. Economics Letters, 83(3), 317-324. https://doi.org/10.1016/j.econlet.2003.10.024

Grazzi, M. (2012). Export and firm performance: Evidence on productivity and profitability of Italian companies. Journal of Industry, Competition and Trade, 12(4), 413-444. https://doi.org/10.1007/s10842-011-0102-9

Greenaway, D., \& Kneller, R. (2007). Industry differences in the effect of export market entry: Learning by exporting? Review of World Economics, 143(3), 416-432. https://doi.org/10.1007/s10290-007-0115-y

Hagemejer, J., \& Kolasa, M. (2011). Internationalisation and economic performance of enterprises: Evidence from Polish firm-level data. The World Economy, 34(1), 74-100. https://doi.org/10.1111/j.1467-9701.2010.01294.x

Hamermesh, D. (2000). The craft of labormetrics. Industrial and Labor Relations Review, 53(3), 363-380. https://d oi.org/10.1177/001979390005300301

Ilmakunnas, P., \& Topi, J. (1999). Microeconomic and macroeconomic influences on entry and exit of firms. Review of Industrial Organization, 15(3), 283-301. https://doi.org/10.1023/A:1007786719982

Iwasaki, I. (2014). Global financial crisis, corporate governance, and firm survival: The Russian experience. Journal of Comparative Economics, 42, 178-211. https://doi.org/10.1016/j.jce.2013.03.015

Kasahara, H., \& Lapham, B. (2008). Productivity and the Decision to Import and Export: Theory and Evidence (CESifo Working Paper Series Working Paper No. 2240, CESifo). Retrieved from CESifo website: http:// www.cesifo-group.de/DocDL/cesifo1_wp2240.pdf

Kox, H., \& Rojas-Romagosa, H. (2010). Exports and productivity selection effects for Dutch firms. De Economist, 158(3), 295-322. https://doi.org/10.1007/s10645-010-9147-0

Lööf, H., \& Andersson, M. (2010). Imports. Productivity and origin markets: The role of knowledge-intensive economies. The World Economy, 33(3), 458-481. https://doi.org/10.1111/j.1467-9701.2010.01263.x

Marques, T., Conzález, I. S., \& Cruz, P. (2011). Downsizing and profitability: An empirical study of Portuguese firms in 1993-2005. International Journal of Business and Economics, 10(1), 13-26.

Mayer, T., \& Ottaviano, G. (2008). The happy few: New facts on the internationalization of European firms. Intereconomics: Review of European Economic Policy, 43(3), 135-148. https://doi.org/10.1007/s10272-008-0247-x

McKinley, W., Zhao, J., \& Rust, K. (2000). A sociocognitive interpretation of organizational downsizing. Academy of Management Review, 25(1), 227-243.

Melitz, M. (2003). The impact of trade on intra-industry reallocations and aggregate industry productivity. Econometrica, 71(6), 1695-1725. https://doi.org/10.1111/1468-0262.00467

Melitz, M., \& Ottaviano, G. (2008). Market size, trade, and productivity. Review of Economic studies, 75(1), 295316. https://doi.org/10.1111/j.1467-937X.2007.00463.x

Melitz, M., \& Redding, S. (2014). Heterogeneous firms and trade. In G. Gopinath, E. Helpman \& K. Rogoff (Eds.), Handbook of international economics (Vol. 4, chap. 1, pp. 1-54). Amsterdam, the Netherlands: Elsevier.

Muûls, M., \& Pisu, M. (2009). Imports and exports at the level of the firm: Evidence from Belgium. The World Economy, 32(5), 692-734. https://doi.org/10.1111/j.1467-9701.2009.01172.x

Robinson, T., van Greuning, H., Henry, E., \& Broihahn, M. (2012). International financial statement analysis (2nd ed.). Hoboken, NJ: CFA Institute, John Wiley and Sons, Inc.

Sousa, C. (2004). Export performance measurement: An evaluation of the empirical research in the literature. Academy of Marketing Science Review, 9(12), 1-23. 
Tamminen, S. (2014). Heterogeneous firms, mark-ups and income inequality. Tjalling C. Koopmans Dissertation Series, USE 023, Utrecht University. (PhD dissertation).

Tamminen, S. (2016). Regional effects or none? Firms' profitability during the Great Recession in Finland Papers in Regional Science, 96(1), 33-59.

Tamminen, S., \& Chang, H.-H. (2012). Company heterogeneity and mark-up variability (VATT Working Paper No. 32). Government Institute of Economic Research, Finland. Retrieved from VATT website: http://vatt-old.posp.fi/ file/vatt_publication_pdf/wp32.pdf

Temouri, Y., Vogel, A., \& Wagner, J. (2013). Self-selection into export markets by business services firms: Evidence from France. Germany and the United Kingdom, Structural Change and Economic Dynamics, 25, 146158. https://doi.org/10.1016/j.strueco.2012.02.004

van den Berg, M. (2014). Does Internationalization Foster Firm Performance?, Tjalling C. Koopmans Dissertation Series, USE 024, Utrecht University. (PhD dissertation).

van den Berg, M., \& van Marrewijk, C. (2017). Imports and productivity: The impact of geography and factor intensity. Journal of International Trade and Economic Development, 26(4), 425-450. https://doi.org/10.1080/ 09638199.2016.1263359

van Marrewijk, C. (2017). International trade. Oxford, UK: Oxford University Press.

Vogel, A., \& Wagner, J. (2010). Higher productivity in importing German manufacturing firms: Self-selection, learning from importing, or both? Review of World Economics, 145(4), 641-665. https://doi.org/10.1007/s10290-009-0031-4

Wagner, J. (2011). From estimation results to stylized facts twelve recommendations for empirical research in international activities of heterogeneous firms. De Economist, 159, 389-412. https://doi.org/10.1007/s10645-0119167-4

Wagner, J. (2012a). Exports, imports and profitability: First evidence for manufacturing enterprises. Open Economies Review, 23(5), 747-765. https://doi.org/10.1007/s11079-011-9235-z

Wagner, J. (2012b). International trade and firm performance: A survey of empirical studies since 2006. Review of World Economics, 148, 235-267. https://doi.org/10.1007/s10290-011-0116-8

\section{SUPPORTING INFORMATION}

Additional Supporting Information may be found online in the supporting information tab for this article.

How to cite this article: van den Berg M, van Marrewijk C, Tamminen S. Trade, productivity and profitability: On profit levels and profit margins. World Econ. 2018;41:2149-2174. https://doi.org/10.1111/twec.12630 